\title{
A Study on Sb and F Doped Tin Oxide Thin Films Preparing in Condition of Different Temperature and Molarity and Their Physical Comparison
}

\begin{abstract}
Ahmet BATTAL ${ }^{1 *}$
Bahattin DUZGUN ${ }^{2}$

ABSTRACT: This article is about tin oxide $\left(\mathrm{SnO}_{2}: \mathrm{Sb}: \mathrm{F}\right)$ thin films prepared $(7$ samples at each experiment step) successfully on the glass substrate by using spray pyrolysis method. Different solution molarities and different substrate temperatures were used to prepare precursor solution and fabricate thin films, respectively. And then these thin film's structural, optical and morphological properties were compared. XRD patterns displayed that the deposited films were polycrystalline with tetragonal structure irrespective of molarity and substrate temperature. Each film has a transmittance of more than $60 \%$ in visible region. Optical band gap values were found to be in the range of 3.74-3.95 $\mathrm{eV}$. The SEM and AFM images demonstrated that nanocrystalline particles covered all film surfaces. The best optimum property was found at thin films $(0.15 \mathrm{M})$ prepared with at $520{ }^{\circ} \mathrm{C}$ and the grains are larger for thin films at $520{ }^{\circ} \mathrm{C}$ when compared with $480{ }^{\circ} \mathrm{C}$. Finally, it is understood that when substrate temperature and molarity increased, more regular structure was obtained.
\end{abstract}

Anahtar Kelimeler: $\mathrm{SnO}_{2}: \mathrm{Sb}: \mathrm{F}$ thin films, spray pyrolysis, solution molarity and substrate temperatures

\footnotetext{
${ }^{1}$ Ahmet BATTAL (Orcid ID: 0000-0003-0208-1564), Mus Alparslan University, Education Faculty, Mus, Turkey

${ }^{2}$ Bahattin DUZGUN (Orcid ID:0000-0000-0000-0000), Ataturk University, Kazim Karabekir Education Faculty, Erzurum, Turkey

*Corresponding author: Ahmet BATTAL, e-mail: a.battal@alparslan.edu.tr
} 


\section{INTRODUCTION}

In latest and sophisticated technological devices like as organic light emitting diode (OLED) (Yusoff et al., 2018), dye-sensitized solar cell (DSSC) (Musyaro'ah et al., 2017), thin film transistors (TFTs) (Priyadarshini et al., 2017), flat panel display (Liu et al., 2018), gas sensor (Kou et al., 2018) and smart windows (Huang et al., 2015), transparent conducting oxide materials (TCO)s are excessively using. The reason for this is due to their excellent properties including high transparency and conductivity, low electric resistivity, chemical inertness and mechanical hardness (Ravichandran et al., 2009; Vazquez-Arreguin et al., 2016). TCOs thin films have deposited with various technique for a long time. It can be given for example spray pyrolysis (Yuwono et al., 2017), spin coating (Kadhim et al., 2017), pulsed laser deposition (Martin et al., 2004), dip coating (Carvalho et al., 2012) and sputtering (Zhu et al., 2017) methods. Among them, it was found that spray pyrolysis method have interesting properties such as simple and inexpensive experimental setup, reproducibility, easily adding of doping materials, preparing thin films with high quality (Tripathi and Shukla, 2014). The properties of TCOs thin films have been fabricated by spray can be changed with substrate temperature, spray time, spray flow rate, nozzle-substrate distance, precursors and solvents etc. (Yuwono et al., 2017). Here, we aimed to compare effect of substrate temperature and molarity on TCOs thin films by spray method (for example $\mathrm{SnO}_{2}: \mathrm{Sb}: \mathrm{F}$ ).

\section{MATERIALS AND METHODS}

\section{Tin Oxide Thin Film Preparation}

In this work, Antimony (Sb) and Fluorine (F) doped tin oxide $\left(\mathrm{SnO}_{2}: \mathrm{Sb}: \mathrm{F}\right)$ thin films were prepared by using a home-made spray pyrolysis method at different substrate temperatures and different molarities. $480{ }^{\circ} \mathrm{C}$ and $520{ }^{\circ} \mathrm{C}$ degrees were chosen for different substrate temperatures.
Substrate temperature is maintained $\pm 10^{\circ} \mathrm{C}$ using a k-type thermocouples. The solution molarity values were kept at $0.05 \mathrm{M}, 0.1 \mathrm{M}$ and $0.15 \mathrm{M}$. All solvent volumes are constantly maintained at 50 $\mathrm{mL}$. Doping weight ratio of $\mathrm{Sb}$ and $\mathrm{F}$, respectively, are $4 \%$ and $30 \%$. For precursor solution, Tin (II) chloride dehydrates $\left(\mathrm{SnCl}_{2} \cdot 2 \mathrm{H}_{2} \mathrm{O}\right)$, antimony (III) chloride $\left(\mathrm{SbCl}_{3}\right)$ and ammonium fluoride $\left(\mathrm{NH}_{4} \mathrm{~F}\right)$, deionized water and hydrochloric acid $(\mathrm{HCl})$ were used. All reagents and organic solvent were purchased from Merck. Glass substrates with (10x10x1) $\mathrm{mm}^{3}$ dimensions were cleaned with Acetone, Isopropyl Alcohol and Deionized water in ultrasonic cleaner. After cleaning, the substrates were dried at $150{ }^{\circ} \mathrm{C}$ in an oven before being used. For making tin precursor solution, $0.564 \mathrm{~g}$ $\mathrm{SnCl}_{2} .2 \mathrm{H}_{2} \mathrm{O}, 0.173 \mathrm{~g} \mathrm{SbCl}_{3}$ and $0.022 \mathrm{~g} \mathrm{NH}_{4} \mathrm{~F}$ were dissolved in $5 \mathrm{ml}$ of HCI. This solution was completed to $50 \mathrm{ml}$ with deionized water. After dissolving, the solution was stirred at $60{ }^{\circ} \mathrm{C}$ for $60 \mathrm{~min}$ to gain homogenous solvent. A syringe filter with 0.2 micron size was used to prevent large particles. Also, in this experiment, the flow rate $\left(10 \mathrm{ml} \cdot \mathrm{min}^{-1}\right)$ of air used as a carrier gas, the nozzle to substrate distance $(40 \mathrm{~cm})$, the spray angle $\left(\alpha=45^{\circ}\right)$, plate rotation speed (20 rpm. $\left.\mathrm{min}^{-1}\right)$ and pressure $\left(0.2 \mathrm{~kg} . \mathrm{cm}^{-2}\right)$ were fixed as a constant. To complete the deposition process, the sprayed films were allowed to cool naturally at room temperature, and some physical properties of thin films investigated and compared. The schematic diagram of this system and other experiment details has been found previous report (Battal et al., 2015).

\section{Characterization}

Rigaku D/Max-IIIC XRD diffractometer with $\mathrm{CuK} \alpha$ radiation $(\lambda=1.5418 \AA$ ), at operating voltage of $30 \mathrm{kV}$, and current of $10 \mathrm{~mA}$, a JEOL SEM (Scanning Electron Microscope) Model 6460. a NT-MDT AFM (Atomic Force Microscope) and a UV-VIS (Perkin Elmer, Lambda 35) spectrophotometer were used to characterize sample's properties. 


\section{RESULTS AND DISCUSSION}

\section{Comparing of XRD Structural Analysis}

Structural properties of $\mathrm{SnO}_{2}: \mathrm{Sb}: \mathrm{F}$ thin films prepared at different concentration and substrate temperature were recorded by Rigaku D/Max-IIIC XRD diffractometer with $\mathrm{CuK} \alpha$ radiation $(\lambda=1.5418 \AA)$. XRD spectra for these thin films are shown in Figure 1 and Figure 2. It was observed from XRD documents that three peaks which compatible with the American Society for Testing and Materials (ASTM) standard along (110), (101) and (211) which indicated the films are polycrystalline in nature and the deposited films have tetragonal (rutile) structure irrespective of molarity of precursor in the solution and substrate temperature.

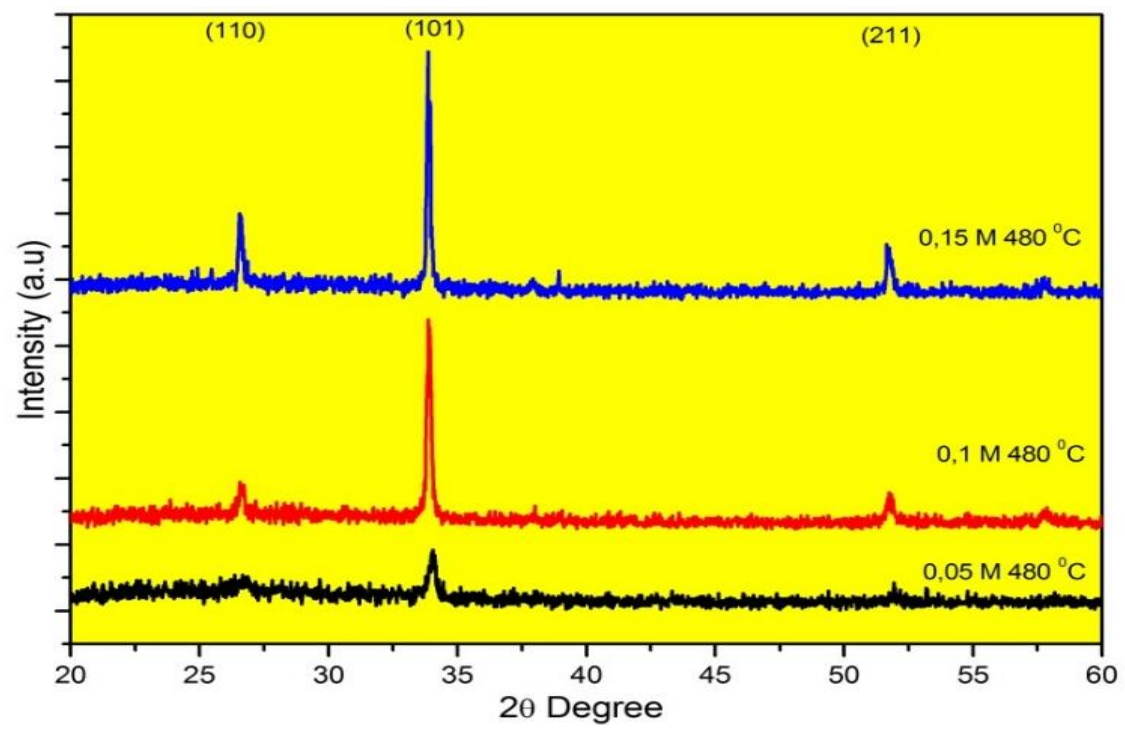

Figure1. The XRD spectra of samples prepared at different molarity and $480{ }^{\circ} \mathrm{C}$ substrate temperature

But, the (101) plane was preferential orientation for the deposited films. Any peaks of impurities have not seen. It was found that as molar concentration and substrate temperatures increase intensities of the all peaks increase. But, intensity of the (101) plane for thin films prepared at $520{ }^{\circ} \mathrm{C}$ is higher than $480{ }^{\circ} \mathrm{C}$. The best optimum properties come into the open to thin films sprayed with $0.15 \mathrm{M}$ and at $520{ }^{\circ} \mathrm{C}$.

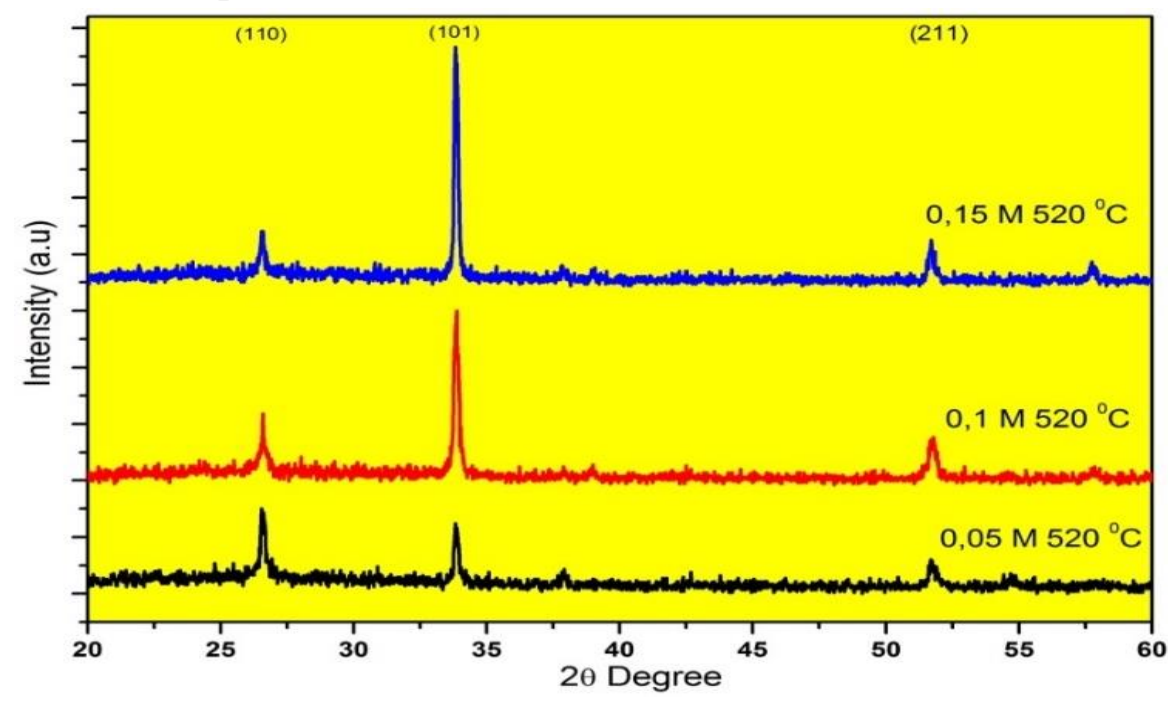

Figure2. The XRD spectra of samples prepared at different molarity and $520{ }^{\circ} \mathrm{C}$ substrate temperature 
Also, The XRD spectra of samples deposited as a function of substrate temperatures and precursor solution concentrations can be seen in Figure 3. Structural parameters for all samples along each crystallographic plane were summarized in Table 1. The grain size (D) of these $\mathrm{SnO}_{2}: \mathrm{Sb}: \mathrm{F}$ thin films is estimated using
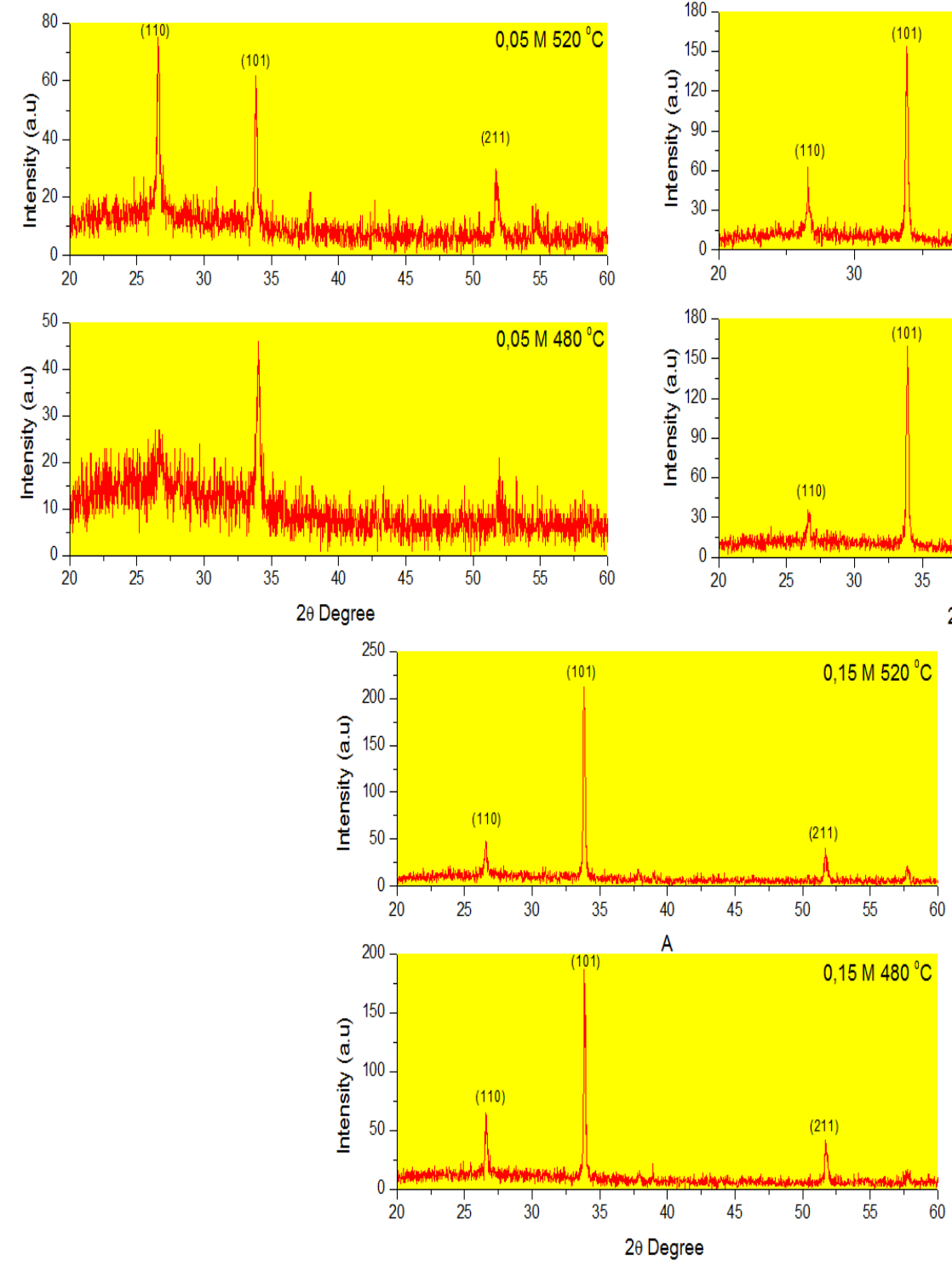

Figure3. The XRD spectra of samples prepared at different substrate temperature and molarity

The interplaner distance (d) for each samples calculated from XRD results by using Bragg's law; $(n \lambda=2 d \sin \Phi)$. As the films have rutile structures, the lattice constants are calculated using $\left(1 / \mathrm{d}^{2}\right)=\left\{\left[\left(\mathrm{h}^{2}+\mathrm{k}^{2}\right) / \mathrm{a}^{2}\right]+\left(\mathrm{l}^{2} / \mathrm{c}^{2}\right)\right.$ equation (Wohlmuth and Adesida, 2015); The

Debye-Scherrer's formula (Vikraman et al., 2016), $D=0.9 \lambda /(\beta \cos \theta)$ where $\lambda$ is the $X$-ray wavelength $(\lambda=1.5418 \AA), \beta$ is the broadening of diffraction line measured at half its maximum intensity in radians (FWHM) and $\theta$ is the Bragg angle.
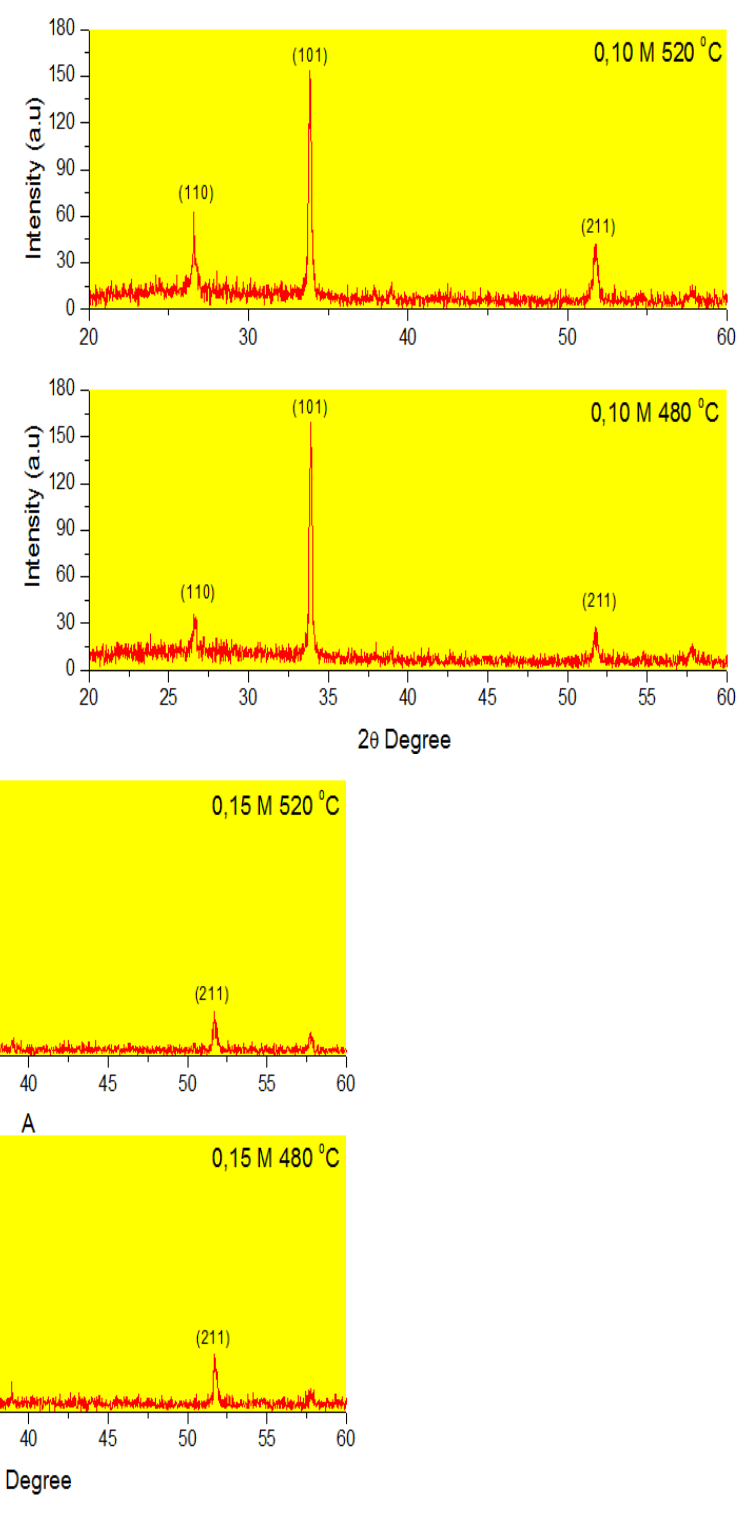
Table 1.The structural parameters of samples prepared at different molarity and substrate temperature

\begin{tabular}{cccccccc}
\hline Samples & $(\mathbf{h k l})$ & $\mathbf{2 \theta}\left(^{\circ}\right)$ & $\mathbf{d}_{\text {std }}(\boldsymbol{\AA})$ & $\mathbf{d}_{\text {cal }}(\mathbf{\AA})$ & $\mathbf{F W H M (})$ & $\mathbf{D}(\mathbf{n m})$ & $\boldsymbol{\delta}\left(\mathbf{l i n e s} \mathbf{~ m}^{-2}\right)$ \\
\hline $\mathbf{0 . 0 5} \mathbf{M}$ & 110 & - & 3.35 & - & - & - & - \\
$\mathbf{4 8 0}{ }^{\circ} \mathbf{C}$ & 101 & 34.12 & 2.644 & 2.629 & 0.07998 & 104 & $9.25 \mathrm{E}+13$ \\
& 211 & 51.87 & 1.764 & .763 & - & - & - \\
\hline \multirow{2}{*}{$\mathbf{0 5} \mathbf{M}$} & 110 & 26.58 & 3.35 & 3.355 & 0.14578 & 57 & $3.07 \mathrm{E}+14$ \\
$\mathbf{5 2 0}{ }^{\circ} \mathbf{C}$ & 101 & 33.86 & 2.644 & 2.648 & 0.20904 & 39.8 & $6.32 \mathrm{E}+14$ \\
& 211 & 51.68 & 1.764 & 1.769 & 0.13331 & 62.4 & $2.57 \mathrm{E}+14$ \\
\hline \multirow{2}{*}{$\mathbf{0 . 1 0} \mathbf{M}$} & 110 & 26.54 & 3.35 & 3.360 & 0.07581 & 110 & $8.30 \mathrm{E}+13$ \\
$\mathbf{4 8 0}{ }^{\circ} \mathbf{C}$ & 101 & 33.82 & 2.369 & 2.652 & 0.20889 & 39.8 & $6.31 \mathrm{E}+14$ \\
& 211 & 51.68 & 1.764 & 1.769 & 0.12 & 63.9 & $2.08 \mathrm{E}+14$ \\
\hline \multirow{2}{*}{$\mathbf{0 . 1 0} \mathbf{M}$} & 110 & 26.72 & 3.35 & 3.337 & 0.05651 & 147 & $4.62 \mathrm{E}+13$ \\
$\mathbf{5 2 0}{ }^{\circ} \mathbf{C}$ & 101 & 33.86 & 2.644 & 2.648 & 0.07444 & 112 & $8.01 \mathrm{E}+13$ \\
& 211 & 51.66 & 1.764 & 1.777 & 0.05424 & 153 & $4.25 \mathrm{E}+13$ \\
\hline \multirow{2}{*}{$\mathbf{0 . 1 5} \mathbf{M}$} & 110 & 26.72 & 3.35 & 3.337 & 0.10746 & 77.4 & $1.67 \mathrm{E}+14$ \\
$\mathbf{4 8 0}{ }^{\circ} \mathbf{C}$ & 101 & 33.88 & 2.644 & 2.647 & 0.20652 & 40.3 & $6.17 \mathrm{E}+14$ \\
& 211 & 51.68 & 1.764 & 1.769 & - & - & - \\
\hline \multirow{2}{*}{$\mathbf{0 . 1 5} \mathbf{M}$} & 110 & 26.54 & 3.35 & 3.36 & 0.21664 & 38.4 & $6.79 \mathrm{E}+14$ \\
$\mathbf{5 2 0}{ }^{\circ} \mathbf{C}$ & 101 & 33.82 & 2.644 & 2.652 & 0.16509 & 50.4 & $3.94 \mathrm{E}+14$ \\
& 211 & 51.68 & 1.764 & 1.769 & - & - & -
\end{tabular}

(hkl) miller indices, 20-The Diffraction Angle, FWHM-Full width at half maximum, d-interplaner distance, D-Grain size, $\delta$-Dislocation density, cal: calculation and std: standard

It was shown at Table 1 that the grain size values changed and improved depending on substrate temperature and molarity. For $480{ }^{\circ} \mathrm{C}$ opposite to $520^{\circ} \mathrm{C}$, grain size of films decreased while molarity increased. For the best thin films at $520{ }^{\circ} \mathrm{C}$, grain size is higher than $480{ }^{\circ} \mathrm{C}$. On the other hand, dislocation density is lower than $480{ }^{\circ} \mathrm{C}$. At lower temperatures, the situation is reversed.
In Table 2. It was found that lattice constants (a and c)were not affected much with substrate temperature and concentration. It was concluded that precursor concentration and temperature is the most important process parameter controlling film structural properties in thin films (Yuwono et al., 2017).

Table 2. Lattices parameters (a and c) of samples prepared at different molarity and substrate temperature

\begin{tabular}{ccccccccc}
\hline Molarity & $\mathbf{T}_{\text {substrate }}$ & $(\mathbf{h k l})$ & $\mathbf{d}_{\text {std }}(\AA)$ & $\mathbf{d}_{\text {cal }}(\AA)$ & $\mathbf{a}_{\text {std }}=\mathbf{b}_{\text {std }}(\AA)$ & $\mathbf{a}_{\text {cal }}=\mathbf{b}_{\text {cal }}(\AA)$ & $\mathbf{c}_{\text {std }}(\AA)$ & $\mathbf{c}_{\text {cal }}(\AA)$ \\
\hline \multirow{2}{*}{$\mathbf{0 . 0 5} \mathbf{M}$} & $480{ }^{\circ} \mathrm{C}$ & 101 & 2.644 & 2.629 & 4.738 & 4.755 & 3.187 & 3.153 \\
& $520{ }^{\circ} \mathrm{C}$ & 101 & 2.644 & 2.652 & 4.738 & 4.751 & 3.187 & 3.196 \\
\hline \multirow{2}{*}{$\mathbf{0 . 1 0 ~ \mathbf { M }}$} & $480{ }^{\circ} \mathrm{C}$ & 101 & 2.644 & 2.647 & 4.738 & 4.719 & 3.187 & 3.197 \\
& $520{ }^{\circ} \mathrm{C}$ & 101 & 2.644 & 2.648 & 4.738 & 4.745 & 3.187 & 3.191 \\
\hline \multirow{2}{*}{$\mathbf{0 . 1 5} \mathbf{M}$} & $480{ }^{\circ} \mathrm{C}$ & 101 & 2.644 & 2.648 & 4.738 & 4.719 & 3.187 & 3.197 \\
& $520{ }^{\circ} \mathrm{C}$ & 101 & 2.644 & 2.652 & 4.738 & 4.751 & 3.187 & 3.191
\end{tabular}

(hkl) miller indices, d-interplaner distance, a, b and c lattice constants, cal: calculation and std: standard 


\section{Comparing of Optical Properties}

The Optical Properties of $\mathrm{SnO}_{2}: \mathrm{Sb}: \mathrm{F}$ thin films are investigated at RT. It was shown that the optical transmittance spectra for these thin films deposited at different substrate temperature and concentration at 300-1000 $\mathrm{nm}$ wavelength in Figure 4.

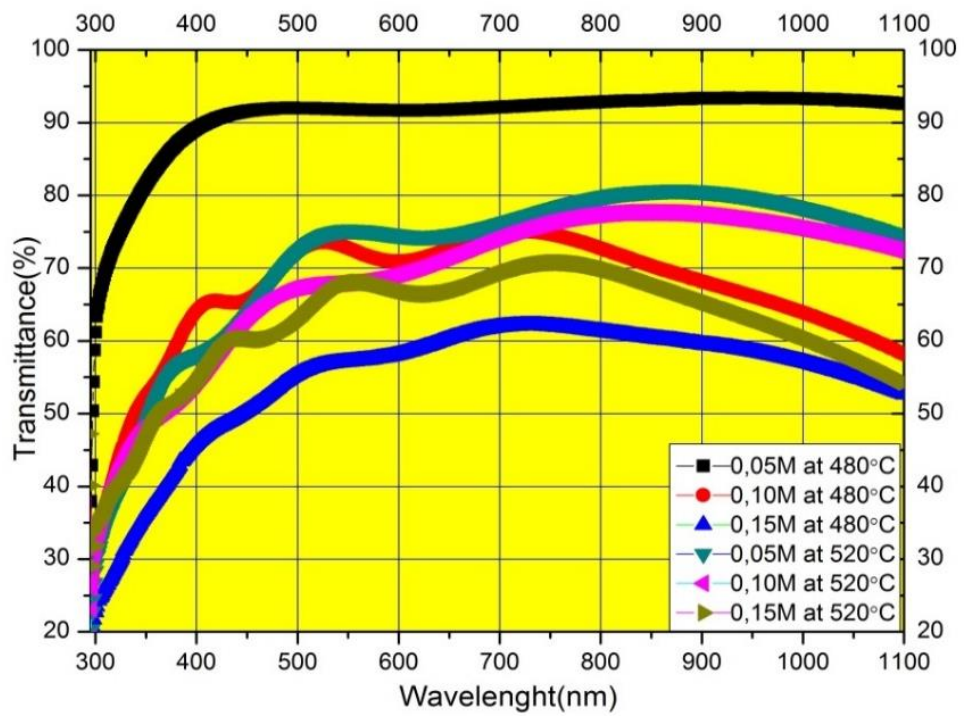

Figure 4. Optical transmittance value versus wavelength of samples prepared at different molarity and substrate temperature

It is understood from UV spectra that all samples have a transmittance of more than $60 \%$ in visible region. As the molarity increased, transmittance of films decreased due to thickness while temperature is stable. But, in the case of solution concentration is not being changed, transmittance of films at $520{ }^{\circ} \mathrm{C}$ is higher than $480{ }^{\circ} \mathrm{C}$ at higher temperature because of good crystalline. Therefore, optical properties of the thin films are depending to temperature and solution molarity. A sudden increase at $480{ }^{\circ} \mathrm{C}$, $0.05 \mathrm{M}$ cannot be understood.

The optical energy gap $\left(E_{g}\right)$ of these thin films can be calculated from the allowed direct transition given by Tauc's eguation $\alpha h v=\mathrm{B}(\mathrm{h} v$ $\left.\mathrm{E}_{\mathrm{g}}\right)^{\mathrm{n}}$ (Kumar et al., 2017); where $\alpha$ is an absorption coefficient, $h$ is Planck's constant, $v$ is the photon frequency and B is a constant.

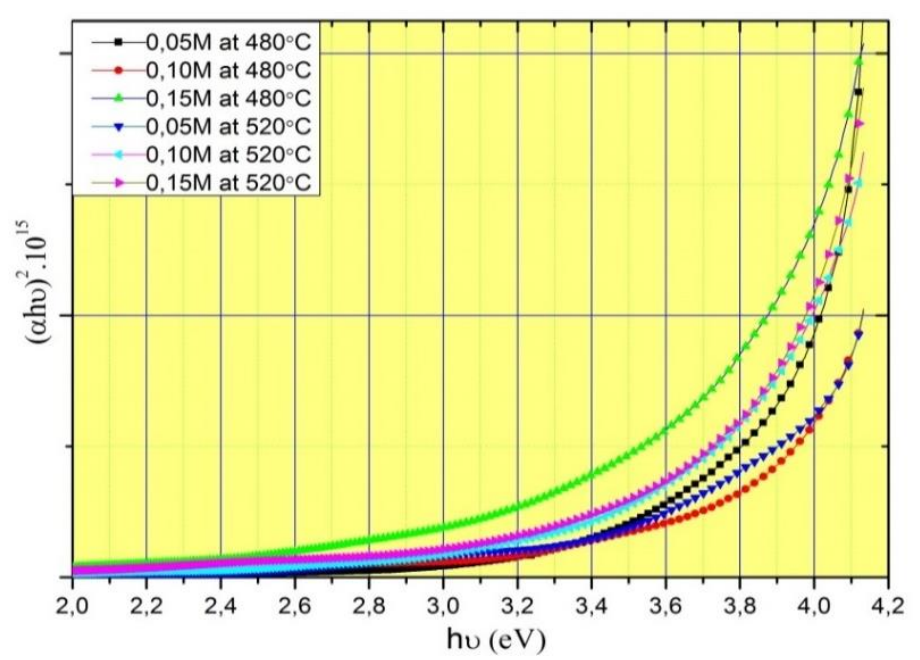

Figure 5. Tauc's Plots of samples prepared at different molarity and substrate temperature 
Table 3. The $\mathrm{T}$ and $\mathrm{E}_{\mathrm{g}}$ values of samples prepared at different molarity and substrate temperature

\begin{tabular}{ccc}
\hline Samples & $\mathbf{T}_{\text {average }}(\boldsymbol{\%}) \mathbf{a t} \mathbf{7 0 0} \mathbf{~ n m}$ & $\mathbf{E}_{\mathbf{g}}(\mathbf{e V})$ \\
\hline $480{ }^{\circ} \mathrm{C} 0.05 \mathrm{M}$ & 92.13 & 3.95 \\
$480{ }^{\circ} \mathrm{C} 0.10 \mathrm{M}$ & 74.85 & 3.85 \\
$480{ }^{\circ} \mathrm{C} 0.15 \mathrm{M}$ & 61.90 & 3.74 \\
$520{ }^{\circ} \mathrm{C} 0.05 \mathrm{M}$ & 76.16 & 3.89 \\
$520{ }^{\circ} \mathrm{C} 0.10 \mathrm{M}$ & 74.00 & 3.84 \\
$520{ }^{\circ} \mathrm{C} 0.15 \mathrm{M}$ & 69.12 & 3.78 \\
\hline
\end{tabular}

The optical band gap values determined by extrapolating the linear curve that intercepts the energy axis (Kumar et al., 2017) were presented in Table 3 and drawn at Figure 5. It is observed that $\mathrm{SnO}_{2}: \mathrm{Sb}: \mathrm{F}$ thin films have wide optical band energy. Also $E_{g}$ values for these thin films were decreased with an increase in molarity. The reduction in band gap can be due to the presence of unstructured defects, which could increase the localized states of density in the band gap, thus decreasing the energy gap (Kumar et al., 2017; El-Zahed et al., 2002). As substrate temperature is increased, $\mathrm{E}_{\mathrm{g}}$ values at $520{ }^{\circ} \mathrm{C}, 0.15 \mathrm{M}$ are higher than $480{ }^{\circ} \mathrm{C}$ well-adjusted with XRD results.

\section{Comparing of SEM Surface Morphologic Analysis}

The study of surface morphology of $\mathrm{SnO}_{2}: \mathrm{Sb}: \mathrm{F}$ thin films sprayed at different concentration and substrate temperature by using spray pyrolysis method has been carried out. Figure 6 are pictures displaying that surface morphologies of these thin films are strongly interrelated to the solution molarity and substrate temperature. The SEM images revealed that nanocrystalline particles covered all substrate surfaces irrespective of temperature and molarity and surface morphology is uniform and homogenous. However, it has been observed that the voids and clusters of particles in film surfaces produced at low temperatures have been reduced when the temperature and concentration which greatly affects the quality of the film are increasing.

\section{Comparing of AFM Topographic Analysis}

The AFM topographic study of these thin films was characterized by a NT-MDT AFM Microscope. Respectively, Figure 7 and Figure 8 show the 2-D and 3-D AFM images of $\mathrm{SnO}_{2}: \mathrm{Sb}: \mathrm{F}$ thin films deposited as a function of substrate temperatures and precursor solution concentrations. The AFM images exhibited that the prepared thin films are to be made of nanocrystalline particles, uniform, homogeneous almost all surfaces. Some of grains are like human oral teeth, another one is ice cream cone or conical shape shaped grains. The AFM images (both) clearly show that the grains are larger for thin films at $520{ }^{\circ} \mathrm{C}$ when compared with $480{ }^{\circ} \mathrm{C}$. When temperature and molarity increased, a regular structure was obtained. These observations strongly support the results obtained from the XRD data (Table 1). The size of the grains is equal with calculated from the XRD data. On the other hand, if solution molarity is increasing, the intergranular spacing is diminishing. Some overgrown grains seem to be stacked at certain favorable sites for thin films at $520{ }^{\circ} \mathrm{C}$ and $0.10 \mathrm{M}$ which confirmed SEM graph and RMS value. Such a variation in grain size values has been reported by several researchers (Moholkar et al., 2008a, 2008b); Ikhmayies and Ahmad-Bitar, 2012). 


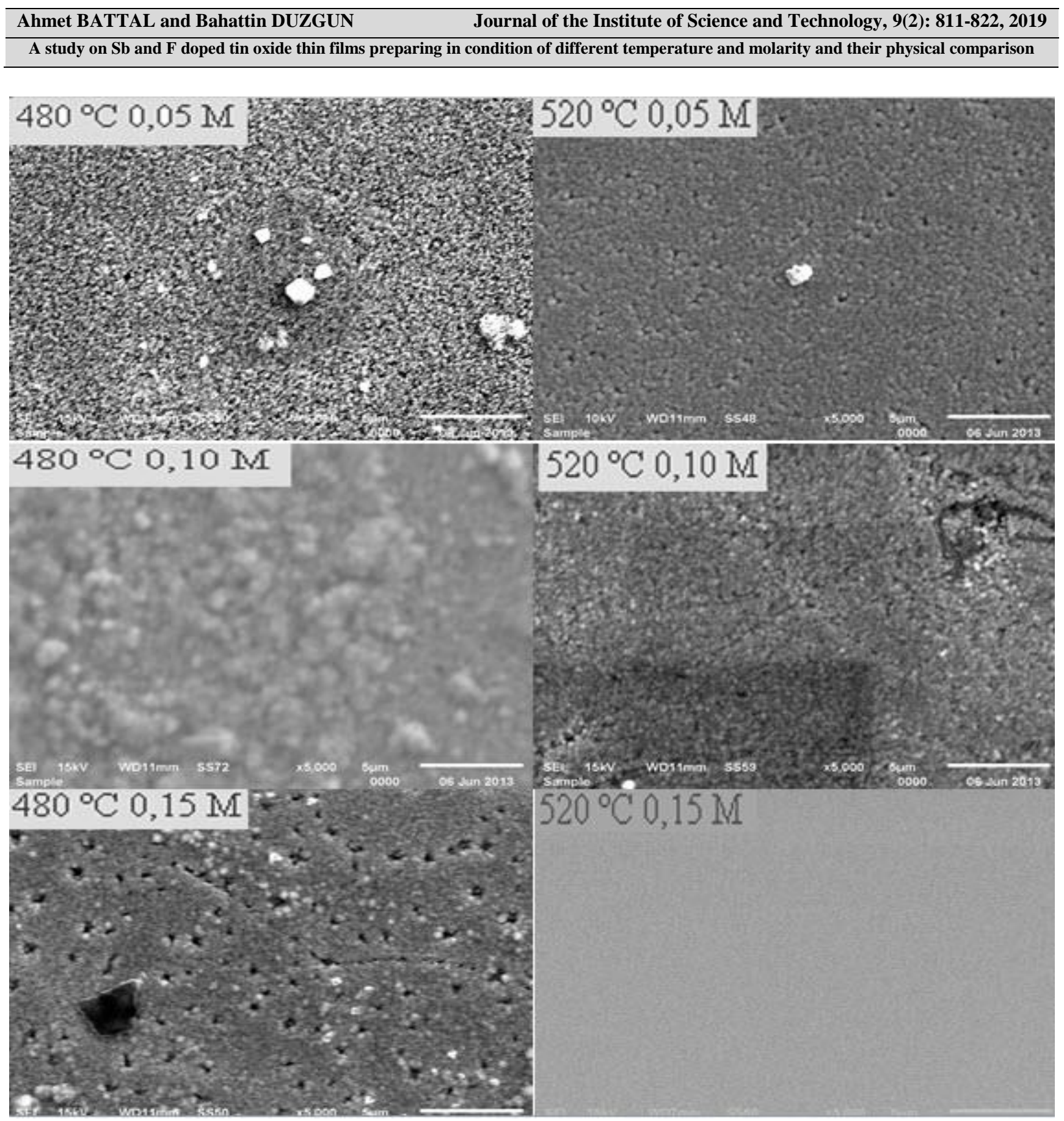

Figure 6.SEM images of samples prepared at different molarity and substrate temperature 


\begin{tabular}{cc}
\hline Ahmet BATTAL and Bahattin DUZGUN & Journal of the Institute of Science and Technology, 9(2): 811-822, 2019 \\
\hline A study on Sb and F doped tin oxide thin films preparing in condition of different temperature and molarity and their physical comparison
\end{tabular}

(a)

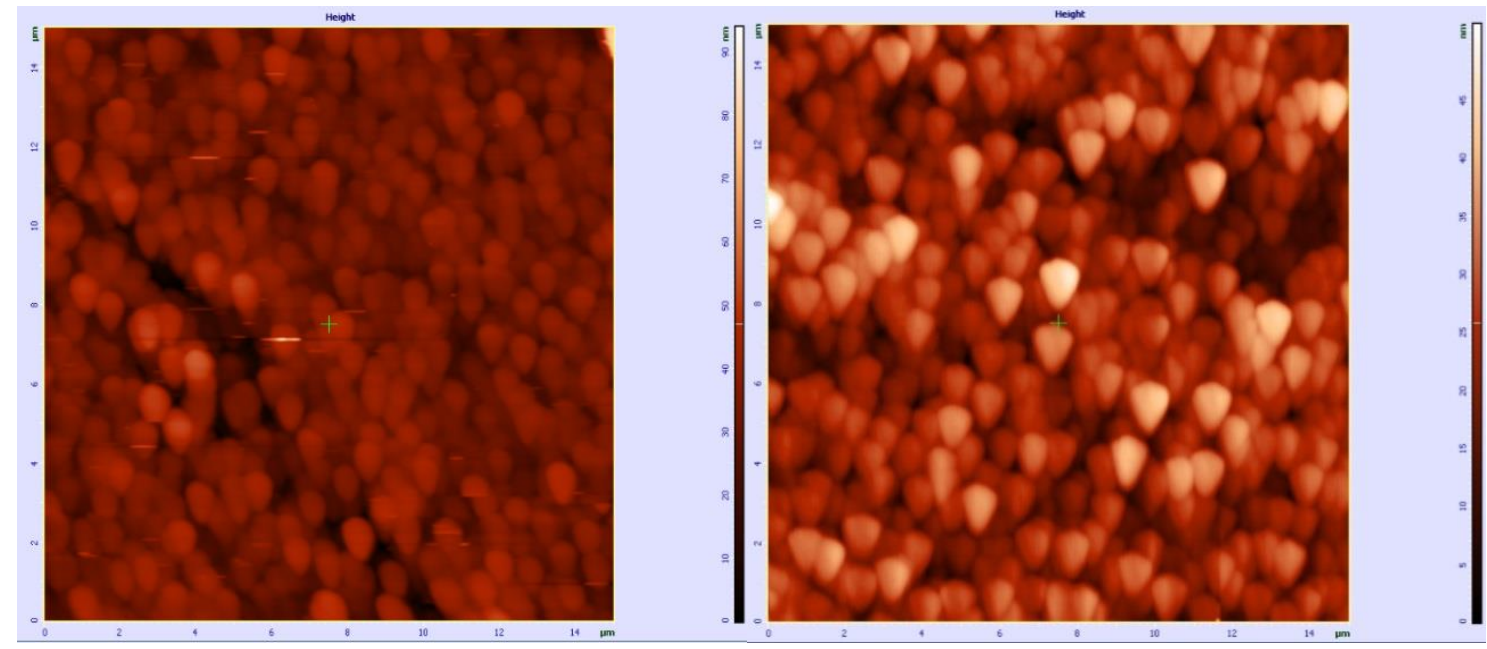

(b)
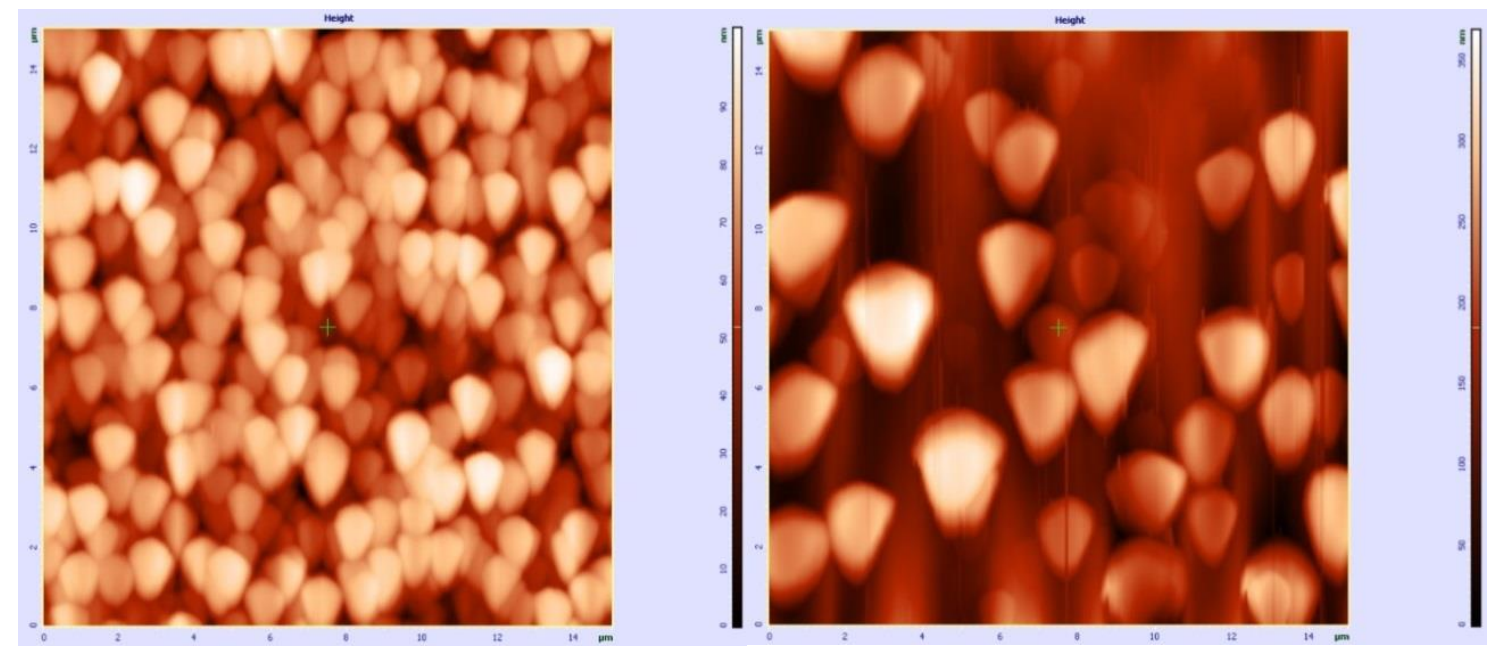

(c)
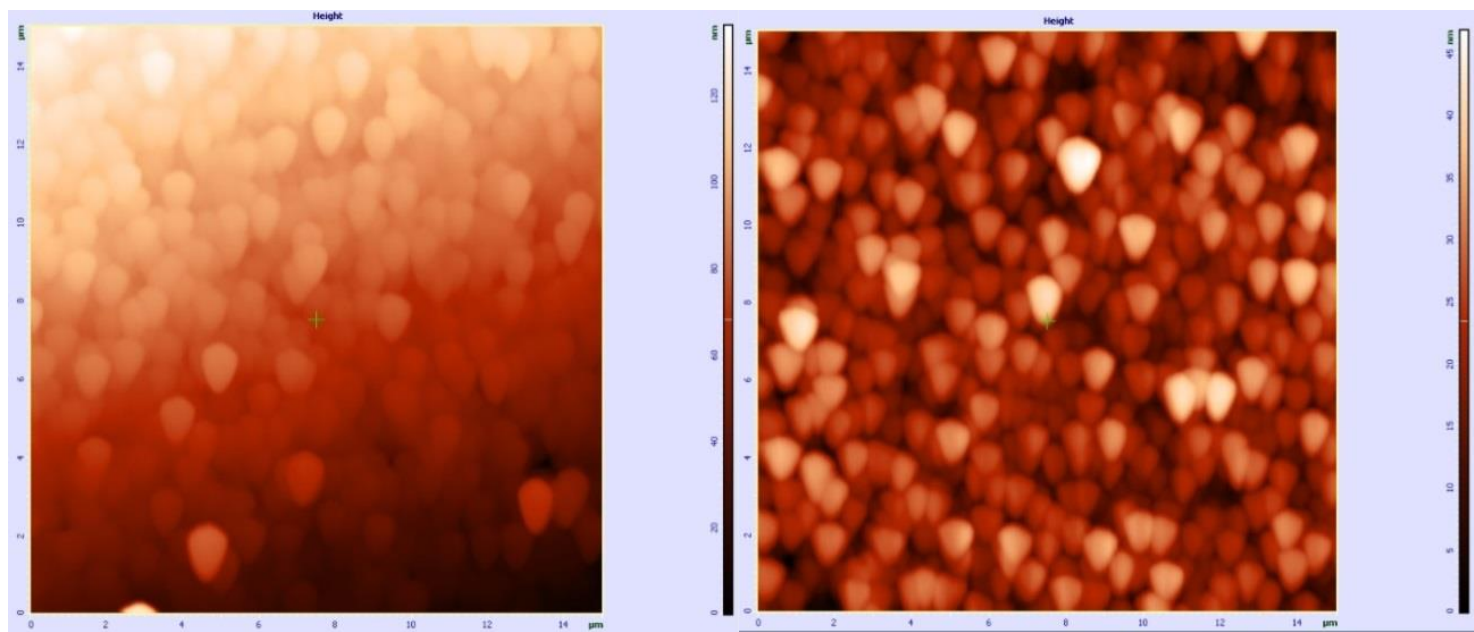

Figure 7. 2-Dimension AFM images of samples prepared at different molarity and substrate temperature (a) $0.05 \mathrm{M}$ (b) $0.10 \mathrm{M}$ and (c) $0.15 \mathrm{M}$ at $480{ }^{\circ} \mathrm{C}$ (left) and $520{ }^{\circ} \mathrm{C}$ (right) substrate temperature 
(a)

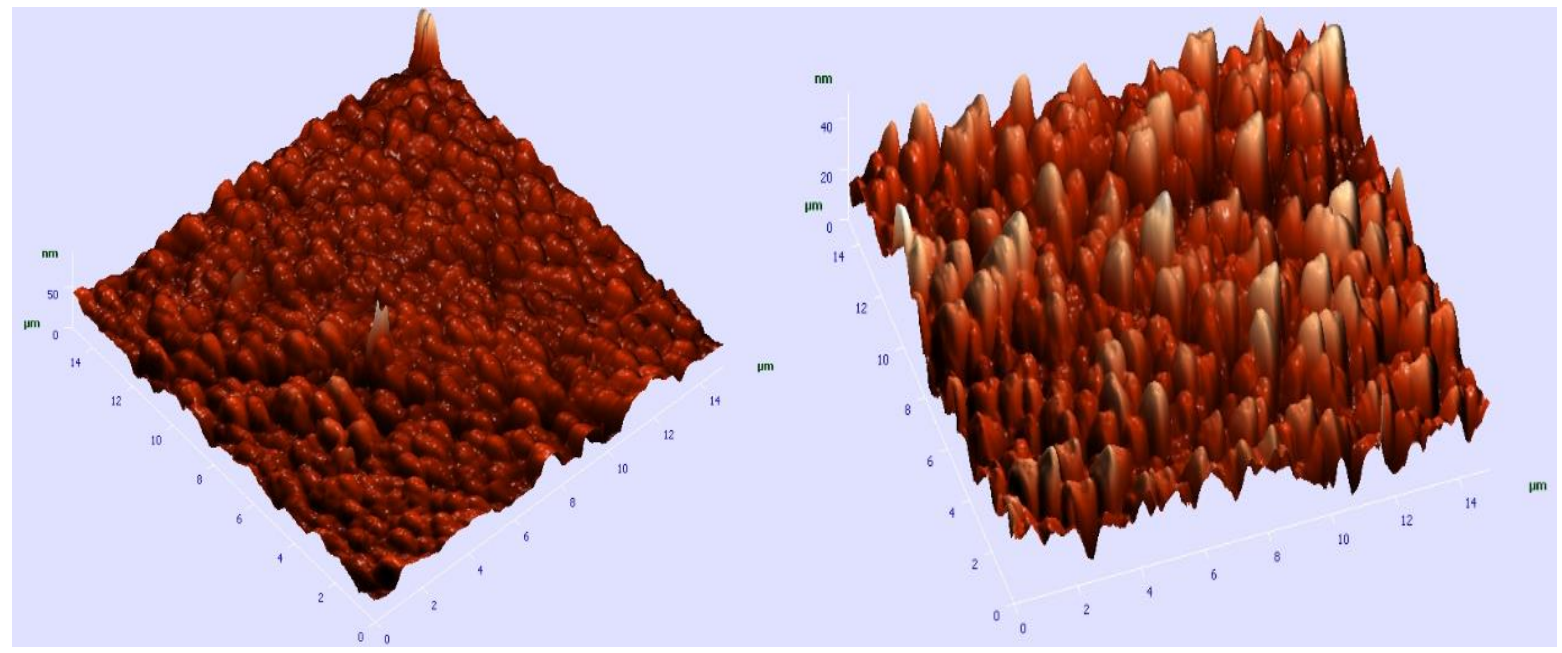

(b)

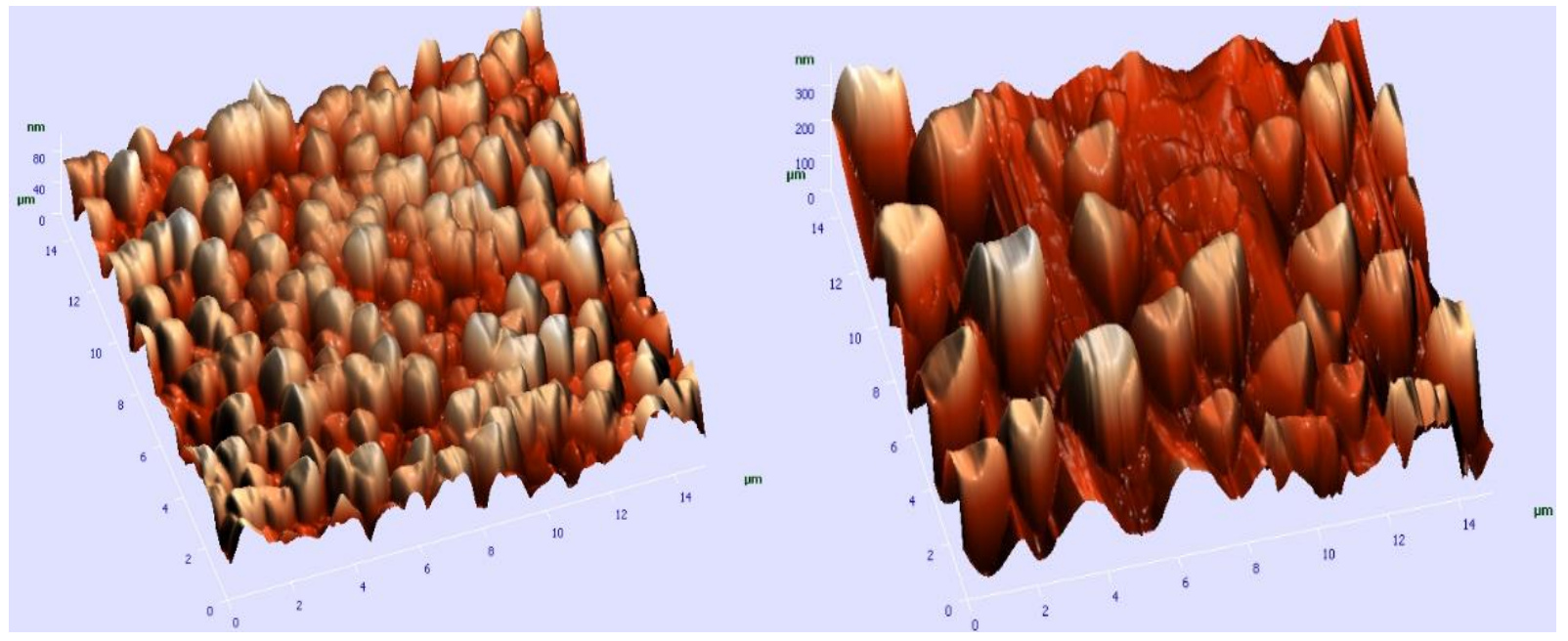

(c)

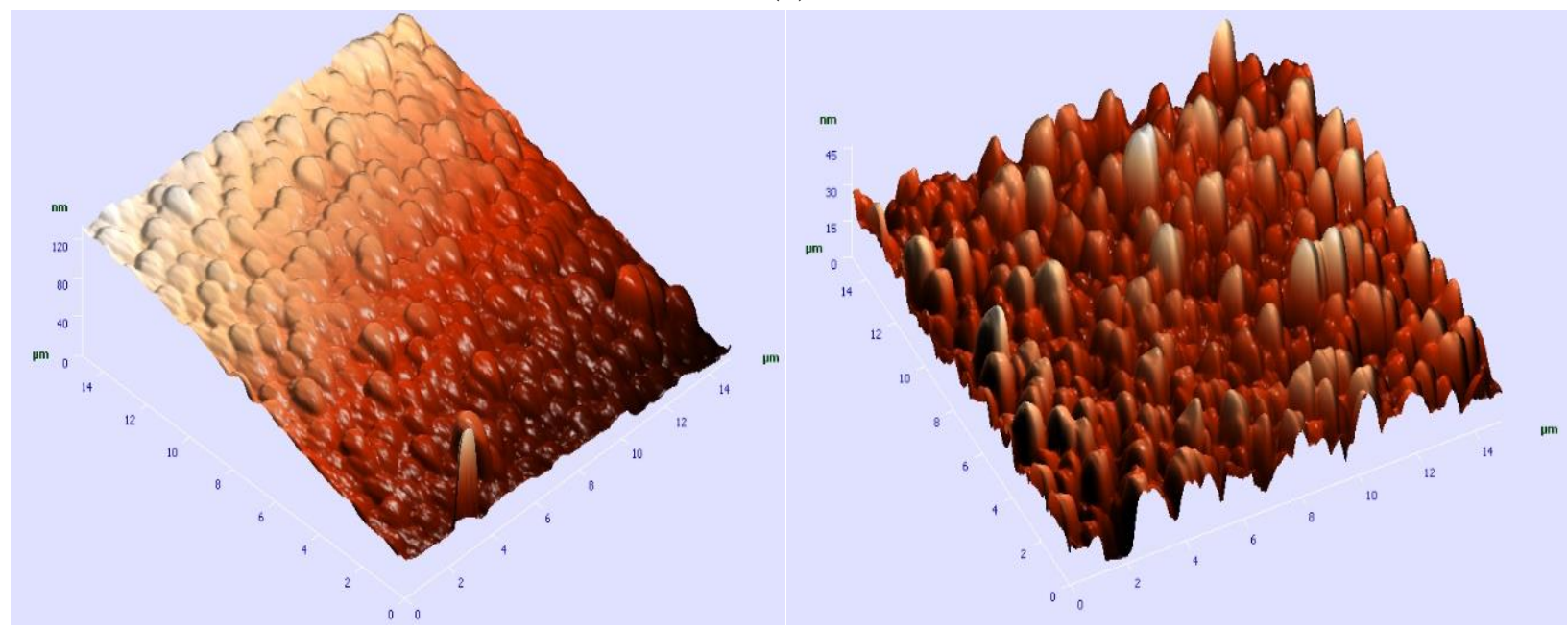

Figure 8. 3-Dimension AFM images of samples prepared at different molarity and substrate temperature (a) $0.05 \mathrm{M}$ (b) $0.10 \mathrm{M}$ and (c) $0.15 \mathrm{M}$ at $480{ }^{\circ} \mathrm{C}$ (left) and $520{ }^{\circ} \mathrm{C}$ (right) substrate temperature 
The values of surface RMS (Root mean square roughness) depended on substrate temperature and molarity are seen in Table 4.

Table 4. The RMS values of samples prepared at different molarity and substrate temperature

\begin{tabular}{ccc}
\hline Solution Molarity & RMS (nm) at 480 ${ }^{\circ} \mathbf{C}$ & RMS (nm) at 520 ${ }^{\circ} \mathbf{C}$ \\
\hline $0.05 \mathrm{M}$ & $22.5383 \mathrm{~nm}$ & $7.83088 \mathrm{~nm}$ \\
$0.10 \mathrm{M}$ & $14.2396 \mathrm{~nm}$ & $65.9065 \mathrm{~nm}$ \\
$0.15 \mathrm{M}$ & $17.3141 \mathrm{~nm}$ & $9.65524 \mathrm{~nm}$ \\
\hline
\end{tabular}

\section{CONCLUSION}

Antimony $(\mathrm{Sb})$ and Fluorine $(\mathrm{F})$ doped tin oxide thin films $\left(\mathrm{SnO}_{2}: \mathrm{Sb}: \mathrm{F}\right)$ were deposited successfully on the glass substrate by spray pyrolysis technique at different solution molarities and different substrate temperatures and their properties compared. XRD results clearly revealed that the prepared films were polycrystalline with tetragonal (rutile) structure irrespective of molarity of precursor in the solution and substrate temperature and thin films had three peaks along (110), (101) and (211). SEM and AFM images demonstrated homogeneous along almost all surfaces and some grains are like human oral teeth, another one is ice cream cone or conical shaped grains. The AFM images clearly show that the grains are larger for thin films at $520{ }^{\circ} \mathrm{C}$ when compared with $480{ }^{\circ} \mathrm{C}$. $\mathrm{E}_{\mathrm{g}}$ values changed 3.74$3.95 \mathrm{eV}$. Each film has a transmittance of more than $60 \%$ in visible region. As the molarity increased, transmittance of films decreased due to thickness while temperature is stable. It is found that the best optimum property was found at thin films $(0.15 \mathrm{M})$ prepared with at $520{ }^{\circ} \mathrm{C}$. Finally, it was understood from results that substrate temperature and solution molarity is necessary for making thin film with good atomization and optimum properties and for materials to be used on optic and electric applications area.

\section{ACKNOWLEDGEMENTS}

The authors thank for support to The Council of Higher Education and Atatürk University Scientific Research Projects (2011/218) Centre Turkey.

\section{REFERENCES}

Battal A, Tatar D, Kocyigit A, Duzgun B, 2015. Materials Focus, 4: 445-456.

Carvalho DHQ, Schiavon MA, Raposo MT, de Paiva R, Alves JLA, Paniago RM, Speziali NL, Ferlauto AS, Ardisson JD, 2012. 15th Brazilian Workshop on Semiconductor Physics, 28: 22-27.

El-Zahed H, El-Korashy A, Rahem MA, 2002. Vacuum, 68: 19-27.

Huang H, Ng MH, Wu YL, Kong LB, 2015. Materials \& Design, 88: 384-389.

Ikhmayies, S.J. and Ahmad-Bitar, R.N., 2012. Using $\mathrm{HF}$ rather than $\mathrm{NH} 4 \mathrm{~F}$ as doping source for spray-deposited $\mathrm{SnO} 2: \mathrm{F}$ thin films. Journal of Central South University of Technology, 19, 791-796.

Kadhim IH, Abu Hassan H, 2017. Journal of Electronic Materials, 46: 1419-1426.

Kou XY, Xie N, Chen F, Wang TS, Guo LL, Wang C, Wang QJ, J Ma, Sun YF, Zhang H, Lu GY, 2018. Sensors and Actuators BChemical, 256: 861-869. 
Kumar KDA, Valanarasu S, Jeyadheepan K, Kim H-S, Vikraman D, 2017. Journal of Materials Science: Materials in Electronics, 29: 3648-3656.

Liu, XZ, Ning, HL, Chen, WF, Fang, ZQ, Yao, RH, Wang, XF, Deng, YX, Yuan, WJ, Wu, WJ, Peng, JB, 2018. Nanomaterials, 8: 293-307.

Martin EJJ, Yan M, Lane M, Ireland J, Kannewurf CR, Chang RPH, 2004. Thin Solid Films, 461: 309-315.

Moholkar, A.V., Pawar, S.M., Rajpure, K.Y. and Bhosale, C.H., 2008a. Effect of concentration of $\mathrm{SnCl} 4$ on sprayed fluorine doped tin oxide thin films. Journal of Alloys and Compounds, 455, 440-446.

Moholkar, A.V., Pawar, S.M., Rajpure, K.Y., Almaric, S.N., Patil, P.S. and Bhosale, C.H., 2008b. Solvent-dependent growth of sprayed FTO thin films with mat-like morphology. Solar Energy Material Solar Cells. 92, 1439-1444.

Musyaro'ah, IH, Indayani W, Gunawan B, Yudhoyono G, Endarko, 2017. International Conference on Engineering, Science and Nanotechnology, 2016. (Icesnano 2016), 1788.

Priyadarshini DM, Mannam R, Rao MSR, DasGupta N, 2017. Applied Surface Science, 418: 414-417.

Ravichandran K, Muruganantham G, Sakthivel B, Philominathan P, 2009. Journal of Ovonic Research, 5: 63-69.
Ravichandran K, Muruganantham G, Saravanakumar K, Karnan S, Kannan B, Chandramohan R, Sakthivel B, 2009. Surface Engineering, 25: 82-87.

Tripathi A, Shukla RK, 2014. Bulletin of Materials Science, 37: 417-423.

Vazquez-Arreguin, R, Aguilar-Frutis, M, Falcony-Guajardo, C, Castaneda-Galvan, A, Mariscal-Becerra, L, GallardoHernandez, S, Alarcon-Flores, G, GarciaRocha, M, 2016. ECS Journal of Solid State Science And Technology, 5: 3, Q101- Q 107.

Vikraman D, Park HJ, Kim SI, Thaiyan M, 2016. Journal of Alloys and Compounds, 686: 616-627.

Wohlmuth W, Adesida I, Thin Solid Films, 2015. 479: 223-231.

Yusoff, ARBM , Gavim, AEX, Macedo, AG, da Silva, WJ, Schneider, FK, Teridi, MAM, 2018. Materials Today Chemistry, 10: 104111.

Yuwono AH, Arini T, Lalasari LH, Sofyan N, Ramahdita G, Nararya A, Firdiyono F, Andriyah L, Subhan A, 2017. International Journal of Technology, 8: 1336.

Zhu BL, Liu F, Li K, Lv K, Wu J, Gan ZH, Liu J, Zeng DW, Xie CS, 2017. Ceramics International, 43: 10288-10298. 